\title{
Effect of fat content and homogenization under conventional or ultra-high- pressure conditions on interactions between proteins in rennet curds
}

\author{
A. Zamora, ${ }^{*}$ A. J. Trujillo, ${ }^{*}$ E. Armaforte, $\dagger$ D. S. Waldron,, and A. L. Kelly ${ }^{1}$ \\ ${ }^{*}$ CERPTA, XaRTA, XiT, MALTA Consolider Group, Departament de Ciència Animal i dels Aliments, Universitat Autònoma de Barcelona, \\ 08193 Bellaterra, Spain \\ †School of Food and Nutritional Sciences, University College Cork, Cork, Ireland
}

\begin{abstract}
The objective of this study was to investigate the influence of conventional and ultra-high-pressure homogenization on interactions between proteins within drained rennet curds. The effect of fat content of milk $(0.0,1.8$, or $3.6 \%)$ and homogenization treatment on dissociation of proteins by different chemical agents was thus studied. Increasing the fat content of raw milk increased levels of unbound whey proteins and calcium-bonded caseins in curds; in contrast, hydrophobic interactions and hydrogen bonds were inhibited. Both homogenization treatments triggered the incorporation of unbound whey proteins in the curd, and of caseins through ionic bonds involving calcium salts. Conventional homogenization-pasteurization enhanced interactions between caseins through hydrogen bonds and hydrophobic interactions. In contrast, ultra-highpressure homogenization impaired hydrogen bonding, led to the incorporation of both whey proteins and caseins through hydrophobic interactions and increased the amount of unbound caseins. Thus, both homogenization treatments provoked changes in the protein interactions within rennet curds; however, the nature of the changes depended on the homogenization conditions.
\end{abstract}

Key words: homogenization, ultra-high-pressure homogenization, protein interaction, rennet curd

\section{INTRODUCTION}

The enzyme chymosin (the principal active agent in rennet) cleaves $\kappa-\mathrm{CN}$ at the surface of casein micelles, which reduces the net negative charge and steric repulsion between micelles, destabilizing them sufficiently to allow coagulation. Rennet-hydrolyzed micelles thus become susceptible to aggregation, and a 3-dimensional gel network is formed (McMahon and Brown, 1984). Fat globules participate in, to a relatively limited ex-

Received January 16, 2012.

Accepted April 25, 2012.

${ }^{1}$ Corresponding author: a.kelly@ucc.ie tent, formation of the protein network, being largely physically entrapped therein, but the fat globule membrane may play a structural role in gels (Michalski et al., 2002).

Homogenization of milk reduces the size of fat globules and increases the moisture content of cheese and cheese yield, due to increased fat recovery (Peters, 1956; Jana and Upadhyay, 1992). However, homogenization also affects protein structure and causes casein micelles and whey proteins to become associated with the fat globule membrane (Michalski et al., 2002). These interactions between fat and proteins lead to lower curd firmness during rennet coagulation, curd shattering during cutting, and improper curd matting (Peters, 1956; Green et al., 1983; Jana and Upadhyay, 1992).

Ultra-high-pressure homogenization (UHPH) is based on the same operating principle as conventional homogenization, but current developments in the design of UHPH systems allow pressures of up to $350 \mathrm{MPa}$ to be reached. Upon UHPH treatment, the fluid is exposed to high turbulence, shear, and cavitation forces, which may be partly transformed into thermal energy, resulting in the heating of the fluid (Hayes and Kelly, 2003). Previous studies with milk have reported temperature increases of 16 to $19^{\circ} \mathrm{C} / 100 \mathrm{MPa}$ (Hayes and Kelly, 2003; Pereda et al., 2007). However, the holding time markedly depended on the UHPH equipment.

In terms of the effects of UHPH on the coagulation properties of milk, conflicting results have been obtained, depending on both the applied pressure and the milk fat content. The coagulation time is reduced for skim milk (Sandra and Dalgleish, 2007; Lodaite et al., 2009) and full-fat milk homogenized at $\leq 200$ MPa (Zamora et al., 2007). However, the rate of curd firming for full-fat milk UHPH-treated at $\geq 200 \mathrm{MPa}$ is increased, with a concomitant increase in gel strength (Hayes and Kelly, 2003; Zamora et al., 2007). Rennetinduced gels from UHPH-treated skim milk show a brittle texture (Lodaite et al., 2009). Zamora et al. (2012b) observed that, although the coagulation properties of milk were enhanced by UHPH, the cheesemaking properties were somewhat altered; UHPH of milk resulted in difficulties when cutting the curd, due to 
crumbling and improper curd matting because of poor cohesion of the grains. The resulting cheeses were firmer and less deformable than control samples (Zamora et al., 2011). These alterations might partly be explained by differences in the nature of proteins within the curd, as well as their interactions. Indeed, a recent study on the effect of UHPH on fat-protein interactions showed that UHPH results in the formation of new chimerical particles; casein molecules, released through partial disruption of casein micelles, were directly bonded to the milk fat globule membrane (MFGM), and varying levels of whey proteins, especially $\beta-L G$, were also adsorbed onto the MFGM (Zamora et al., 2012a).

One strategy for understanding the interactions between proteins within cheese curd involves using different chemical dissociating agents, which disrupt specific types of bond or interaction (Lefebvre-Cases et al., 1998). For example, hydrophobic interactions and hydrogen bonds can be disrupted by SDS or urea, respectively, whereas ionic bonds involving calcium salts are broken by the chelating effect of EDTA. The amount of proteins dissociated by dispersing curds in the presence of the appropriate agent, followed by ultracentrifugation, indicates the action of the agent on the network and, thus, the presence and relative importance of specific interactions. Subsequent identification of dissociated proteins by electrophoresis can identify which proteins are involved in each type of interaction. The aim of the current study was, thus, to identify the differences in the protein-protein interactions in curds from conventionally homogenized-pasteurized and UHPH-treated milk, with different fat contents, compared with those produced from raw milk.

\section{MATERIALS AND METHODS}

\section{Milk Supply and Treatments}

Raw whole milk was obtained from a local dairy farm and skimmed at 40 to $45^{\circ} \mathrm{C}$ at pilot scale (final fat content of $0.05 \% \pm 0.01 \mathrm{wt} / \mathrm{vol}$ ); fat contents were determined using a MilkoScan FT 120 apparatus (Foss Electric A/S, Hillerød, Denmark; IDF, 2000). Skimmed and whole milk were then mixed for standardization to fat contents (means $\pm \mathrm{SD}$ ) of $1.8 \pm 0.1$ and $3.6 \pm 0.1 \%$ (wt/vol).

The UHPH treatment was done by a single-stage process at $300 \mathrm{MPa}$ (nm-Gen $7400 \mathrm{H}$ model; Stansted Fluid Power Ltd., Harlow, UK) at an inlet temperature of $30^{\circ} \mathrm{C}$, which was determined in previous studies to be the best UHPH-treatment conditions for cheesemaking (Zamora et al., 2007, 2012b). During treatment, the milk temperature at the valve reached (mean \pm SD) $90 \pm 2^{\circ} \mathrm{C}$ (for $\sim 0.7 \mathrm{~s}$ ). Milk samples, the outlet temperature of which was lowered to approximately $50^{\circ} \mathrm{C}$ by a cooling coil with tap water, were immediately cooled to $4^{\circ} \mathrm{C}$ in iced water. The UHPH treatment was compared with conventional homogenization combined with pasteurization. Conventional treatment consisted of 2-stage homogenization at $60^{\circ} \mathrm{C}(15-\mathrm{MPa}$ first stage and 3-MPa second stage; model APV 1000; APV homogenizers AS, Albertslund, Denmark), followed by batch pasteurization $\left(63^{\circ} \mathrm{C}\right.$ for $\left.30 \mathrm{~min}\right)$. Skimmed and standardized raw milk samples were also collected for further analysis.

\section{Particle Size Distribution of Milk Samples}

The particle size distribution in milk samples was determined by light-scattering using a Mastersizer model S particle size analyzer (Malvern Instruments Ltd., Malvern, UK), equipped with a 3000F (reverse Fourier) lens as described by Lodaite et al. (2009). The volumeweighted mean diameter $[\mathbf{D}(\mathbf{4 , 3})]$ and surface-weighted mean diameter $[\mathbf{D}(\mathbf{3}, \mathbf{2})]$ were determined.

\section{Sample Preparation}

Milk samples were warmed to $32^{\circ} \mathrm{C}$ and recombinant chymosin (180 international milk clotting units $/ \mathrm{mL}$; Maxiren 180; DSM Food Specialties, Seclin Cedex, France) was added at a level of $0.074 \%$ (vol/vol). After coagulation at $32^{\circ} \mathrm{C}$ for 30 min, curds were vertically cut with a spatula and centrifuged at $1,500 \times g$ for $15 \mathrm{~min}$ at $20^{\circ} \mathrm{C}$ (Beckman J2-21 with rotor JA-14; Beckman Instruments France S.A., Gagny, France) and pellets were recovered, after decanting whey, for yield estimation (Daviau et al., 2000) and for further analysis.

\section{Composition Analysis of Curds}

Protein and fat content of drained curds were determined in triplicate using the Kjeldahl method (IDF, 1993) and the van Gulik method (ISO, 1975), respectively. Curds were analyzed in triplicate for TS (IDF, $2004)$ to calculate their moisture content $(100$ - TS) and express protein and fat content on a dry basis. The estimated yield of curds on a wet basis, expressed as grams of curd recovered per $100 \mathrm{~g}$ of milk, was determined by weighing the curds obtained.

\section{Dissociation Tests}

Protein-protein interactions in drained curds were studied following a modification of the method of Lefebvre-Cases et al. (1998). Samples of drained curds $(10 \mathrm{~g})$ were dispersed in $40 \mathrm{~mL}$ of aqueous dissociating solutions containing either $2 \mathrm{~m} M$ EDTA (pH 10.0), $1 \%$ 
(wt/vol) SDS, or $6 M$ urea. For a control sample, curds were mixed with Milli-Q water (Millipore Corp., Billerica, MA). Mixtures of curds and dissociating agent were dispersed for $1 \mathrm{~min}$ at 9,000 rpm (Ultra-Turrax T 25; Janke and Kunkel, IKA Labortechnik, Staufen, Germany), and the resulting mixtures were ultracentrifuged at $86,000 \times g$ for $40 \mathrm{~min}$ at $20^{\circ} \mathrm{C}$ (Beckman Optima LE-80K with rotor type $50.2 \mathrm{Ti}$; Beckman Instruments France S.A.).

Immediately after ultracentrifugation, supernatants were analyzed for total protein using a modified version of the method of Lowry et al. (1951). Supernatants were diluted in Milli-Q water $[25 \%$ ( $\mathrm{vol} / \mathrm{vol}$ ) for dissociation in Milli-Q water or EDTA or $2.5 \%$ ( $\mathrm{vol} /$ vol) for dissociation in SDS or urea]. Diluted samples $(200 \mu \mathrm{L})$ were mixed with $2.1 \mathrm{~mL}$ of Lowry reagent D [1:1:98 mixture of $1 \%$ (wt/vol) copper sulfate, $1 \%$ (wt/vol) sodium potassium tartrate, and $2 \%$ (wt/vol) sodium carbonate in $0.1 \mathrm{M} \mathrm{NaOH}]$. After $10 \mathrm{~min}$ at room temperature, Folin-Ciocalteu phenol reagent (250 $\mathrm{mL}$ of a 1:1 dilution with Milli-Q water) was added and color development was allowed to proceed for 30 min at room temperature. The absorbance at $750 \mathrm{~nm}$ was then measured with a spectrophotometer (model Cary 300 Bio; Varian Inc., Palo Alto, CA), and the protein content quantified using a standard curve of BSA standards in the range 0 to $1 \mathrm{mg}$ of protein $/ \mathrm{mL}$. All chemicals were purchased from Sigma-Aldrich Chemie (Steinheim, Germany).

Both qualitative and quantitative analysis of the main proteins extracted were carried out by SDS-PAGE analysis under reducing conditions using separating and stacking gels containing 14 or $4 \%$ acrylamide, respectively. Supernatants mixed with double-strength reducing buffer (Laemmli, 1970) were loaded onto the gels $(20 \mu \mathrm{L}$ for Milli-Q water and EDTA, or $3 \mu \mathrm{L}$ for SDS and urea) together with BSA standard $(10 \mu \mathrm{g})$ and a wide-range molecular weight marker (M4038; SigmaAldrich Chemie). Gels were run at $200 \mathrm{~V}$, stained using 0.1\% (wt/vol) Coomassie Brilliant Blue R250 in a 5:1:4 mixture of methanol, acetic acid, and distilled water, and destained in 2 steps with 5:1:4 and 7:5:88 mixtures of methanol, acetic acid, and distilled water, respectively. Distained gels were scanned using a calibrated Bio-Rad GS800 densitometer (Bio-Rad Laboratories Inc., Hercules, CA).

\section{Statistical Analysis}

The whole experiment was repeated on 3 independent occasions. Data were analyzed by ANOVA using the GLM procedure of Statgraphics (Statgraphics Inc., Chicago, IL). The least significant difference test was used for comparison of sample data, and evaluations were based on a significance level of $P<0.05$.

\section{RESULTS AND DISCUSSION}

\section{Particle Size Distribution of Milk Samples}

Both homogenization treatments significantly decreased $\mathrm{D}(4,3)$ values compared with raw milk (Table $1)$; conventional homogenization-pasteurization resulted in significantly lower values than UHPH, and the effect of the former was independent of the level of fat. However, in the case of UHPH, 3.6\% fat milk samples had significantly higher values than UHPH-treated milk samples with 0.0 or $1.8 \%$ fat. When the volume of the particles is taken into account, low levels of large particles are detected by higher $\mathrm{D}(4,3)$ values. Indeed, previous studies have shown that UHPH triggers both coalescence and aggregation of particles, resulting in a small number of very large particles (Hayes and Kelly, 2003; Zamora et al., 2007). No significant differences in $\mathrm{D}(3,2)$ values were found between $0.0 \%$ fat milk samples subjected to different treatments. When fat was present, both homogenization treatments decreased $\mathrm{D}(3,2)$, and UHPH yielded significantly lower values than conventional homogenization-pasteurization.

Conventionally homogenized-pasteurized milk showed a monomodal distribution of sizes on a plot of volume against particle size, ranging from 0.05 to $3.0 \mu \mathrm{m}$, with a peak at approximately $0.2 \mu \mathrm{m}$ (data not shown). For UHPH-treated milk samples, the observed distributions were bimodal; the principal peak was also at approximately $0.2 \mu \mathrm{m}$, but the particles ranged from 0.05 to $1.0 \mu \mathrm{m}$. The smallest particles $(<0.1 \mu \mathrm{m})$ were more abundant in UHPH-treated milk than in conventionally homogenized-pasteurized milk. A second peak of particles, of diameters from 2.0 to $5.0 \mu \mathrm{m}$, was observed, but represented less than $5 \%$ of the total particles. Such results are broadly in accordance with previous studies (Hayes and Kelly, 2003; Zamora et al., 2007).

\section{Estimated Yield, and Moisture, Fat, and Protein Contents of Curds}

When fat was present, both homogenization treatments significantly increased estimated curd yield on a wet basis compared with that obtained from raw milk (Table 1). However, the effect of UHPH was greater than that of conventional homogenization-pasteurization. The increases for 3.6 and $1.8 \%$ fat milk samples were 51 and $54 \%$ for UHPH-treated milk samples, and 19 and $23 \%$ for conventionally homogenized-pasteurized milk samples, respectively. Higher estimated yields 
Table 1. Volume- $[\mathrm{D}(4,3)]$ and surface- $[\mathrm{D}(3,2)]$ weighted mean diameters of particles in milk and wet yield, moisture content, and fat and protein contents (on a dry basis) of drained curds ${ }^{1}$

\begin{tabular}{|c|c|c|c|c|c|c|}
\hline Treatment $^{2}$ & $\begin{array}{l}\mathrm{D}(4,3) \\
(\mathrm{nm})\end{array}$ & $\begin{array}{l}\mathrm{D}(3,2) \\
(\mathrm{nm})\end{array}$ & $\begin{array}{c}\text { Wet yield } \\
\text { ( } \mathrm{g} \text { of curd } / 100 \mathrm{~g} \text { of milk) }\end{array}$ & $\begin{array}{l}\text { Moisture content } \\
\text { (g 100/g of curd) }\end{array}$ & $\begin{array}{c}\text { Fat content } \\
(\mathrm{g} / 100 \mathrm{~g} \text { of } \mathrm{TS})\end{array}$ & $\begin{array}{l}\text { Protein content } \\
\text { (g/100 } \mathrm{g} \text { of } \mathrm{TS})\end{array}$ \\
\hline $0.0-\mathrm{R}$ & $944 \pm 136^{\mathrm{d}}$ & $211 \pm 8^{\mathrm{ef}}$ & $18.38 \pm 0.16^{\mathrm{e}}$ & $79.38 \pm 0.17^{\mathrm{d}}$ & $4.41 \pm 0.69^{\mathrm{g}}$ & $65.47 \pm 1.92^{\mathrm{a}}$ \\
\hline $0.0-\mathrm{H}$ & $139 \pm 95^{\mathrm{f}}$ & $212 \pm 6^{\text {ef }}$ & $21.02 \pm 1.06^{\mathrm{e}}$ & $80.73 \pm 0.21^{\mathrm{c}}$ & $7.78 \pm 0.79^{\mathrm{f}}$ & $59.16 \pm 1.83^{\mathrm{b}}$ \\
\hline $1.8-\mathrm{R}$ & $3,176 \pm 63^{\mathrm{b}}$ & $634 \pm 11^{\mathrm{b}}$ & $25.95 \pm 0.37^{\mathrm{d}}$ & $77.20 \pm 0.19^{\mathrm{f}}$ & $32.38 \pm 0.70^{\mathrm{d}}$ & $43.76 \pm 0.88^{\mathrm{c}}$ \\
\hline $1.8-\mathrm{H}$ & $212 \pm 23^{\mathrm{f}}$ & $259 \pm 2^{\mathrm{d}}$ & $31.87 \pm 1.52^{\mathrm{c}}$ & $79.55 \pm 0.34^{\mathrm{d}}$ & $35.02 \pm 1.31^{\mathrm{c}}$ & $40.29 \pm 1.18^{\mathrm{d}}$ \\
\hline $1.8-\mathrm{U}$ & $605 \pm 22^{\mathrm{e}}$ & $191 \pm 2^{\mathrm{ef}}$ & $39.99 \pm 1.22^{\mathrm{b}}$ & $83.12 \pm 0.24^{\mathrm{a}}$ & $29.34 \pm 0.74^{\mathrm{e}}$ & $42.15 \pm 0.87^{\mathrm{cd}}$ \\
\hline $3.6-\mathrm{U}$ & $1,277 \pm 152^{\mathrm{c}}$ & $220 \pm 12^{\mathrm{e}}$ & $52.32 \pm 2.30^{\mathrm{a}}$ & $82.26 \pm 0.27^{\mathrm{b}}$ & $42.55 \pm 0.63^{\mathrm{b}}$ & $32.61 \pm 1.00^{\mathrm{e}}$ \\
\hline
\end{tabular}

${ }^{\mathrm{a}-\mathrm{g}}$ Values within a column without common superscripts are significantly different $(P<0.05)$.

${ }^{1}$ Mean value \pm standard error; $\mathrm{n}=6$ for raw milk $(\mathrm{R})$ and $\mathrm{n}=3$ for milk subjected to conventional homogenization-pasteurization (H) and milk subjected to ultra-high-pressure homogenization (U; estimated yield) or $\mathrm{n}=18$ for $\mathrm{R}$ and $\mathrm{n}=9$ for $\mathrm{H}$ and $\mathrm{U}$ (others).

${ }^{2}$ Values $0.0,1.8$, and 3.6 represent the milk fat content $(\%)$.

were explained in a previous study by higher moisture content, higher recovery of fat, or the incorporation of whey proteins into the curds (or all of these; Zamora et al., 2007).

In the present study, as milk fat content increased, both homogenization treatments increased the moisture content of curds by 2 to $4 \%$ for conventionally homogenized-pasteurized milk, and by up to $9 \%$ for UHPH-treated milk (Table 1). Impaired whey drainage in curds made from homogenized milk has been previously reported (Humbert et al., 1980; Green et al., 1983; Ghosh et al., 1994; Zamora et al., 2007). The water-holding capacity of curds is directly linked to the microstructure of the gels (i.e., porosity or permeability; Walstra et al., 1985); native fat globules act as fillers in the interstices of the network (Lopez and Dufour, 2001), thus reducing the volume available for water. The effects of homogenization on the moisture content of the curd have been attributed to the incorporation of denatured whey proteins and the alteration in the protein-fat structure of the curd (Green et al., 1983; Métais et al., 2006; Zamora et al., 2007).

As expected, the recovery of fat in the curd was significantly higher with increasing fat level in milk (Table 1). Conventional homogenization-pasteurization significantly increased the fat content of curds made from 0.0 and $1.8 \%$ fat milk. An increase in fat in DM content in cheese made using homogenized milk and cream has been reported (Jana and Upadhyay, 1992; Metzger and Mistry, 1994). In contrast, UHPH decreased the recovery of fat, particularly for 3.6 and $1.8 \%$ fat milk. Lanciotti et al. (2006) reported that Caciotta cheeses made from milk high-pressure homogenized at $\leq 100$ $\mathrm{MPa}$ had lower fat content than those made from raw milk. Losses of fat might be due to the presence of very small fat globules that are not retained within the curd and are lost in the whey.
The protein content of curds on a dry basis did not significantly differ between treatments; increasing the fat content of milk from 0.0 to $3.6 \%$ resulted in very large differences in protein content, thus perhaps masking the small effect of the treatments (Table 1). However, both homogenization treatments decreased the protein content of curds, except in the case of UHPH-treated $3.6 \%$-fat milk. Ultra-high-pressure homogenization has been proven to reduce the amount of $\beta-\mathrm{LG}$ and, to a lesser extent, $\alpha$-LA in whey by incorporation of these proteins into the curd (Zamora et al., 2007).

\section{Dissociation of Proteins from Curd}

The levels of dissociation of protein from curd depended markedly on the dissociating agent used (Table 2 ). The amount of protein extracted with Milli-Q water (i.e., unbound proteins) was in the range of 8 to $16 \%$ of the protein content of the curds. These results were similar to those reported for rennet gels (LefebvreCases et al., 1998); no differences in the distribution of the stabilizing bonds have been found between rennetinduced gels and cheese grains (Hinrichs and Keim, 2007). The main unbound proteins were identified as the whey proteins $\beta$-LG and $\alpha$-LA (Figures 1 and 2; Table 3); no para-k-CN or $\gamma_{2^{-}} / \gamma_{3}$-CN were detected. These results suggest that mechanical disruption of the network on macerating in water released the whey protein entrapped in the curd.

Densitometric analysis of protein bands on gels indicated that increasing the milk fat content increased the levels of whey proteins released into the supernatant. The presence of native fat globules may increase the amount of solids susceptible to creation of weak interactions that can be mechanically disrupted. When fat was present, both homogenization treatments increased the dissociation of curd proteins. Homogenization 
Table 2. Effect of dissociating agent on protein content of supernatants ( $\mathrm{g}$ of supernatant protein/100 $\mathrm{g}$ of curd protein $)^{1}$

\begin{tabular}{|c|c|c|c|c|}
\hline Treatment $^{2}$ & Milli-Q water ${ }^{3}$ & EDTA & Urea & SDS \\
\hline $0.0-\mathrm{R}$ & $8.00 \pm 0.37^{\mathrm{f}}$ & $8.74 \pm 0.16^{\mathrm{e}}$ & $81.52 \pm 2.82^{\mathrm{b}}$ & $98.53 \pm 4.25^{\mathrm{cd}}$ \\
\hline $0.0-\mathrm{H}$ & $9.39 \pm 0.24^{\mathrm{e}}$ & $11.36 \pm 0.27^{\mathrm{c}}$ & $87.70 \pm 1.41^{\mathrm{a}}$ & $104.13 \pm 1.22^{\mathrm{bcd}}$ \\
\hline $0.0-\mathrm{U}$ & $8.22 \pm 0.24^{\mathrm{f}}$ & $10.16 \pm 0.27^{\mathrm{d}}$ & $83.29 \pm 1.89^{\mathrm{ab}}$ & $116.57 \pm 4.18^{\mathrm{a}}$ \\
\hline 1.8-R & $9.70 \pm 0.16^{\mathrm{e}}$ & $11.64 \pm 0.16^{\mathrm{c}}$ & $69.11 \pm 1.12^{\mathrm{cd}}$ & $97.08 \pm 1.40^{\mathrm{d}}$ \\
\hline $1.8-\mathrm{H}$ & $12.54 \pm 0.60^{\mathrm{cd}}$ & $15.38 \pm 0.77^{\mathrm{b}}$ & $86.55 \pm 2.75^{\mathrm{ab}}$ & $109.12 \pm 5.32^{\mathrm{ab}}$ \\
\hline $1.8-\mathrm{U}$ & $11.71 \pm 0.25^{\mathrm{d}}$ & $15.77 \pm 0.34^{\mathrm{b}}$ & $68.15 \pm 1.14^{\mathrm{cd}}$ & $106.08 \pm 3.17^{\mathrm{bc}}$ \\
\hline $3.6-\mathrm{R}$ & $12.61 \pm 0.35^{\mathrm{c}}$ & $15.75 \pm 0.33^{\mathrm{b}}$ & $65.96 \pm 2.27^{\mathrm{d}}$ & $99.02 \pm 2.33^{\mathrm{cd}}$ \\
\hline $3.6-\mathrm{H}$ & $16.28 \pm 0.37^{\mathrm{a}}$ & $19.58 \pm 0.69^{\mathrm{a}}$ & $73.41 \pm 1.60^{\mathrm{c}}$ & $107.55 \pm 1.96^{\mathrm{ab}}$ \\
\hline $3.6-\mathrm{U}$ & $14.26 \pm 0.30^{\mathrm{b}}$ & $19.50 \pm 0.87^{\mathrm{a}}$ & $49.25 \pm 2.11^{\mathrm{e}}$ & $83.03 \pm 2.18^{\mathrm{e}}$ \\
\hline
\end{tabular}

${ }^{a-f}$ Values within a column without common superscripts are significantly different $(P<0.05)$.

${ }^{1}$ Mean value \pm standard error; $\mathrm{n}=18$ for raw milk $(\mathrm{R})$ and $\mathrm{n}=9$ for milk subjected to conventional homogenization-pasteurization $(\mathrm{H})$ and milk subjected to ultra-high-pressure homogenization (U).

${ }^{2}$ Values $0.0,1.8$, and 3.6 represent the milk fat content $(\%)$.

${ }^{3}$ Millipore Corp., Billerica, MA.

results in a higher number of small particles, which would increase the degree of interactions. The proportion of unbound $\alpha$-LA released from curds made from UHPH-treated milk was significantly higher than from untreated or conventionally homogenized-pasteurized milk. As UHPH increased the moisture content of curds, more whey proteins would be entrapped in the curd. To a lesser extent, caseins (i.e., $\alpha_{\mathrm{s}}-\mathrm{CN}$ and $\beta-\mathrm{CN}$ ) were also affected. This fact could be explained because homogenization, especially UHPH, may cause partial disintegration of the casein micelles (Sandra and Dalgleish, 2005; Roach and Harte, 2008).

Ethylenediaminotetraacetate, as a chelating agent, disrupts ionic bonds of proteins involving calcium salts. Dissociation in the presence of EDTA slightly increased the amount of protein extracted compared with Milli-Q water alone (Table 2). The main proteins released were caseins and their hydrolysis products (Figures 1 and 2; Table 3). Calcium bonding is, thus, clearly at least partially responsible for casein retention within the curd.

Previous reports on dissociation capacity of EDTA differ significantly. Lefebvre-Cases et al. (1998) obtained $76 \%$ dissociation of protein from rennet gels with $2 \mathrm{~m} M$ EDTA, but did not refer to $\mathrm{pH}$ adjustment when preparing the chemical agent. Gagnaire et al. (2002) subsequently showed that the rate of dissociation varied, depending on EDTA concentration, at $\mathrm{pH}$ 8.0; for $2 \mathrm{~m} M$ EDTA, the amount of calcium present in the supernatant was similar to that found without EDTA, and no casein was released. In a recent study,

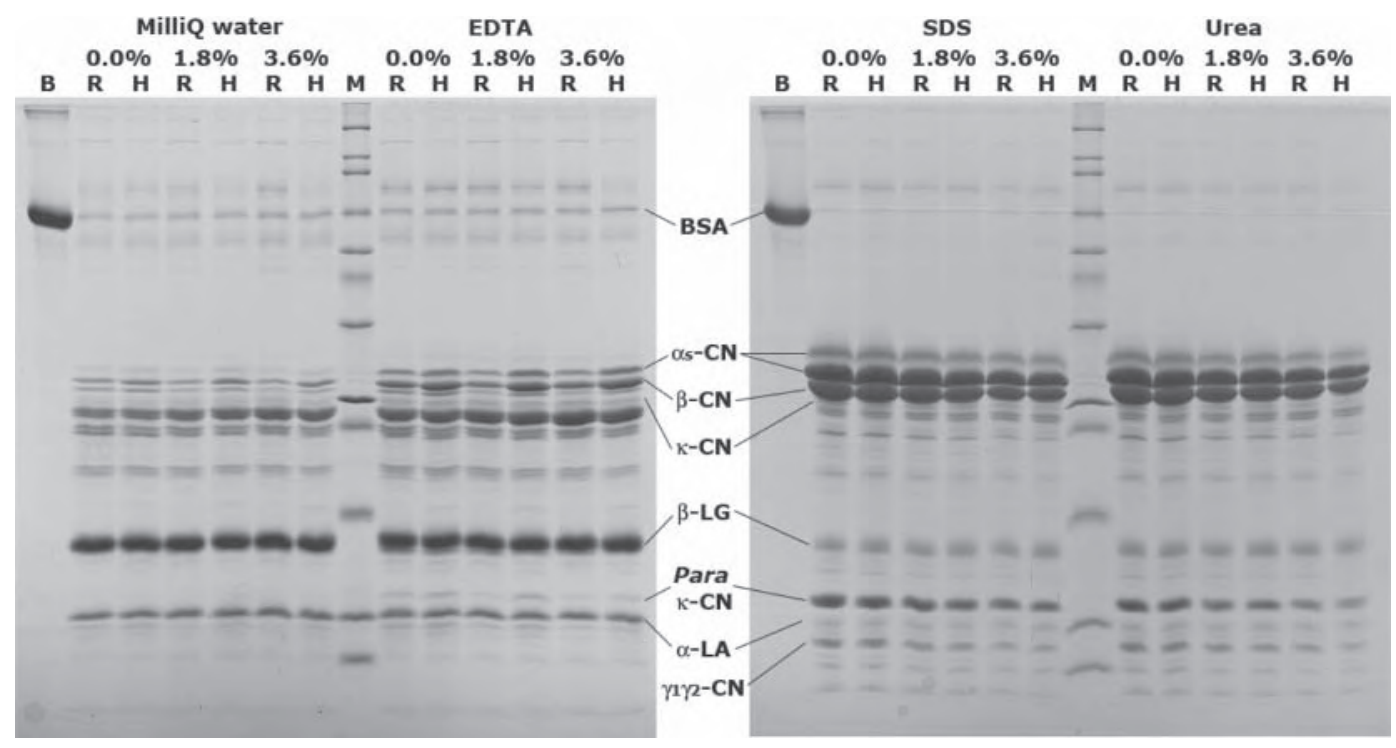

Figure 1. Sodium dodecyl sulfate PAGE electrophoretograms of supernatants obtained on dissociation of drained curds from conventionally homogenized-pasteurized milk $(0.0,1.8$, and $3.6 \%$ are milk fat contents; $\mathrm{R}$ and $\mathrm{H}$ indicate raw milk and milk subjected to conventional homogenization-pasteurization, respectively; B and M are BSA standard and molecular weight markers, respectively). 
Table 3. Levels of proteins in supernatants of curds dissociated by Milli-Q water (Millipore Corp., Billerica, MA) and EDTA (g of dissociated protein/100 g of supernatant protein $)^{1}$

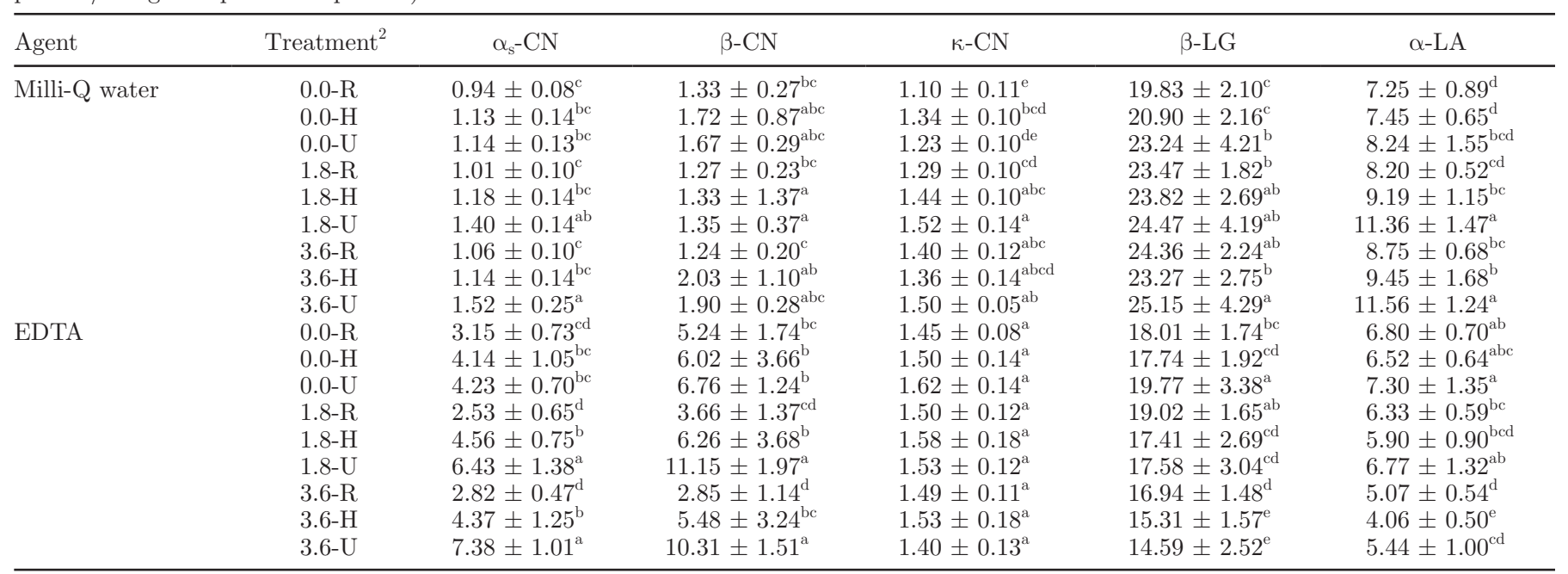

${ }^{\mathrm{a} e \mathrm{e}}$ Values within a column without common superscripts per dissociating agent are significantly different $(P<0.05)$.

${ }^{1}$ Mean value \pm standard error; $\mathrm{n}=6$ for raw milk $(\mathrm{R})$ and $\mathrm{n}=3$ for milk subjected to conventional homogenization-pasteurization $(\mathrm{H})$ and milk subjected to ultra-high-pressure homogenization (U).

${ }^{2}$ Values $0.0,1.8$, and 3.6 are milk fat contents $(\%)$.

Alessi et al. (2007) evaluated the interactions in rennet gels obtained from reconstituted skim milk prepared at 2 different temperatures $\left(25\right.$ or $\left.38^{\circ} \mathrm{C}\right)$, and reported that the amount of protein dissociated by $2 \mathrm{~m} M$ EDTA varied widely; increasing temperature decreased dissociation down to the value obtained without EDTA.

Increasing the milk fat content significantly increased the levels of dissociation of all proteins obtained with EDTA. Independent of the fat content of milk, both homogenization treatments enhanced the dissociation of $\alpha_{\mathrm{s}}-\mathrm{CN}$ and $\beta-\mathrm{CN}$. Calcium bonding could be enhanced by a rearrangement of the mineral balance in milk; UHPH at $300 \mathrm{MPa}$ induces a transfer of minerals from the soluble to the micellar fraction (Zamora et al., 2007).

Urea disrupts hydrogen bonds by denaturing proteins through establishing strong hydrogen bonds with polypeptide groups of proteins. In agreement with previous

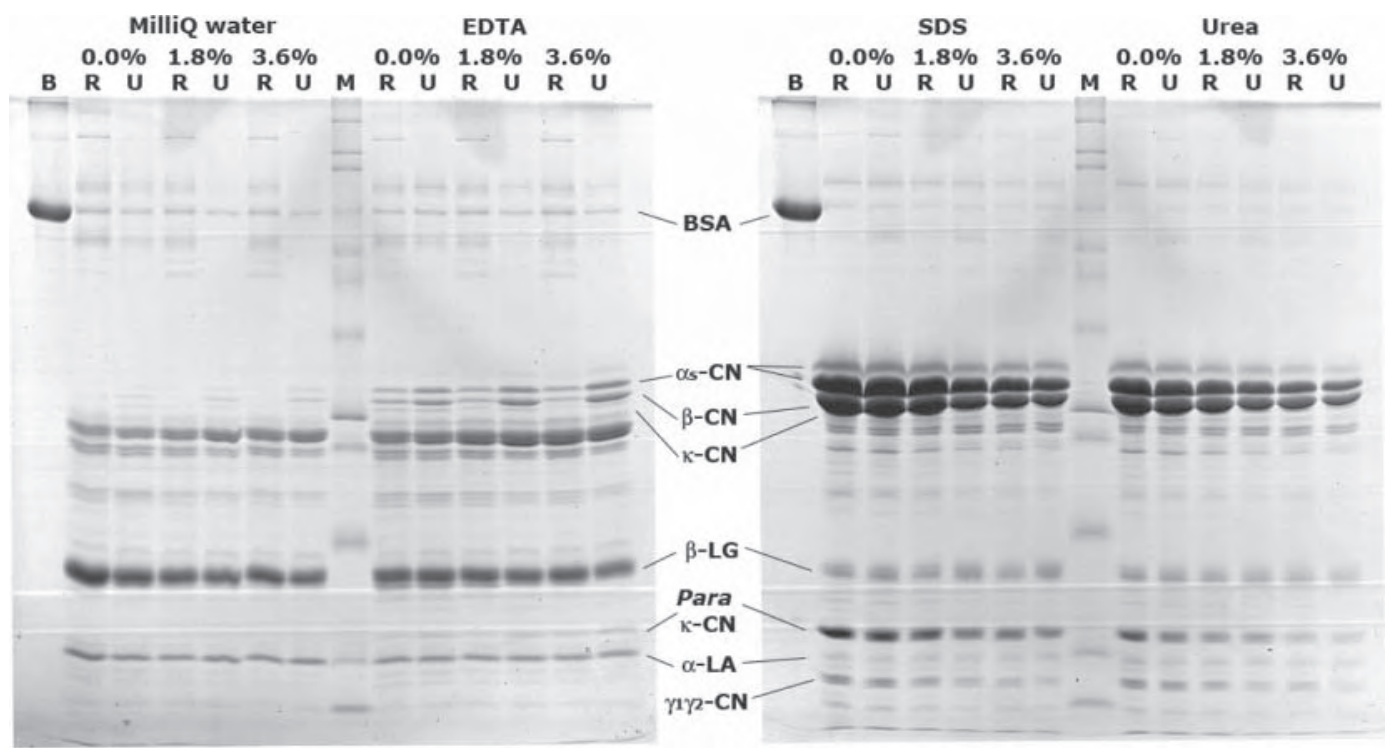

Figure 2. Sodium dodecyl sulfate PAGE electrophoretograms of supernatants obtained on dissociation of drained curds from ultra-highpressure homogenization $(\mathrm{UHPH})$-treated milk $(0.0,1.8$, and $3.6 \%$ are milk fat contents; $\mathrm{R}$ and $\mathrm{U}$ indicate raw milk and milk subjected to $\mathrm{UHPH}$, respectively; B and M are BSA standard and molecular weight markers, respectively). 
Table 4. Levels of proteins in supernatants of curds dissociated by urea and SDS ( $\mathrm{g}$ of dissociated protein/100 g of supernatant protein) ${ }^{1}$

\begin{tabular}{|c|c|c|c|c|c|c|c|c|}
\hline Agent & Treatment $^{2}$ & $\alpha_{\mathrm{s}}-\mathrm{CN}$ & $\beta-\mathrm{CN}$ & $\kappa-\mathrm{CN}$ & $\beta-\mathrm{LG}$ & para-к-CN & $\alpha$-LA & $\gamma_{2^{-}}$and $\gamma_{3^{-}} \mathrm{CN}$ \\
\hline \multirow[t]{6}{*}{ Urea } & $0.0-\mathrm{R}$ & $25.98 \pm 1.91^{\mathrm{f}}$ & $37.63 \pm 2.20^{\mathrm{e}}$ & $3.39 \pm 0.26^{\mathrm{a}}$ & $1.97 \pm 0.20^{\mathrm{d}}$ & $16.08 \pm 1.42^{\mathrm{a}}$ & $1.24 \pm 0.08^{\mathrm{e}}$ & $4.43 \pm 0.67^{\mathrm{a}}$ \\
\hline & $0.0-\mathrm{H}$ & $27.23 \pm 2.58^{\mathrm{ef}}$ & $36.89 \pm 2.62^{\mathrm{e}}$ & $2.43 \pm 0.54^{\mathrm{c}}$ & $1.83 \pm 0.19^{\mathrm{d}}$ & $14.93 \pm 1.13^{\mathrm{ab}}$ & $1.29 \pm 0.15^{\mathrm{de}}$ & $3.15 \pm 0.43^{\mathrm{bc}}$ \\
\hline & $0.0-\mathrm{U}$ & $26.63 \pm 1.86^{\mathrm{ef}}$ & $38.90 \pm 1.45^{\mathrm{e}}$ & $2.53 \pm 0.18^{b c}$ & $1.97 \pm 0.24^{\mathrm{d}}$ & $12.23 \pm 1.81^{\mathrm{bc}}$ & $1.16 \pm 0.11^{\mathrm{e}}$ & $3.46 \pm 0.12^{\mathrm{ab}}$ \\
\hline & $1.8-\mathrm{H}$ & $30.86 \pm 3.88^{\mathrm{de}}$ & $44.11 \pm 4.35^{\text {cde }}$ & $1.99 \pm 0.16^{\mathrm{c}}$ & $2.38 \pm 0.36^{\mathrm{cd}}$ & $10.71 \pm 1.33^{\mathrm{cd}}$ & $1.57 \pm 0.22^{\text {cde }}$ & $2.11 \pm 0.29^{c}$ \\
\hline & $1.8-\mathrm{U}$ & $41.04 \pm 1.96^{\mathrm{b}}$ & $54.47 \pm 3.60^{\mathrm{ab}}$ & $2.63 \pm 0.17^{\mathrm{bc}}$ & $4.29 \pm 0.85^{\mathrm{a}}$ & $10.35 \pm 0.71^{\mathrm{cd}}$ & $2.20 \pm 0.21^{\mathrm{b}}$ & $2.57 \pm 0.18^{\mathrm{bc}}$ \\
\hline & $3.6-\mathrm{R}$ & $37.04 \pm 2.13^{\mathrm{c}}$ & $49.90 \pm 2.68^{\mathrm{bc}}$ & $2.51 \pm 0.14^{\mathrm{c}}$ & $3.08 \pm 0.22^{\mathrm{b}}$ & $4.79 \pm 0.70^{\mathrm{e}}$ & $2.00 \pm 0.12^{\mathrm{bc}}$ & $2.57 \pm 0.14^{\mathrm{bc}}$ \\
\hline \multirow{6}{*}{ SDS } & $0.0-\mathrm{H}$ & $26.05 \pm 2.01^{\mathrm{c}}$ & $34.29 \pm 2.38^{\mathrm{de}}$ & $2.80 \pm 0.28^{\mathrm{b}}$ & $1.76 \pm 0.17^{\mathrm{d}, \mathrm{e}}$ & $16.72 \pm 0.41^{\mathrm{a}}$ & $1.06 \pm 0.10^{\mathrm{de}}$ & $2.50 \pm 0.40^{\mathrm{b}}$ \\
\hline & $0.0-\mathrm{U}$ & $22.25 \pm 0.86^{\mathrm{d}}$ & $30.56 \pm 0.85^{\mathrm{ef}}$ & $3.58 \pm 0.50^{\mathrm{a}}$ & $2.14 \pm 0.19^{\text {cde }}$ & $12.90 \pm 0.29^{\mathrm{b}}$ & $0.87 \pm 0.07^{\mathrm{e}}$ & $3.06 \pm 0.52^{\mathrm{a}}$ \\
\hline & $1.8-\mathrm{R}$ & $26.91 \pm 1.25^{\mathrm{c}}$ & $36.74 \pm 1.31^{\mathrm{cd}}$ & $2.14 \pm 0.36^{\mathrm{c}}$ & $1.75 \pm 0.12^{\mathrm{de}}$ & $14.08 \pm 0.92^{\mathrm{ab}}$ & $1.11 \pm 0.07^{\mathrm{d}}$ & $1.77 \pm 0.27^{\mathrm{cd}}$ \\
\hline & $1.8-\mathrm{H}$ & $29.13 \pm 2.08^{\mathrm{bc}}$ & $39.73 \pm 2.30^{\mathrm{bc}}$ & $2.21 \pm 0.11^{\mathrm{bc}}$ & $2.16 \pm 0.18^{\text {cde }}$ & $15.41 \pm 1.05^{\mathrm{ab}}$ & $1.33 \pm 0.11^{\mathrm{c}}$ & $2.08 \pm 0.14^{\mathrm{bcd}}$ \\
\hline & $1.8-\mathrm{U}$ & $31.03 \pm 1.72^{\mathrm{b}}$ & $42.99 \pm 2.26^{\mathrm{b}}$ & $1.96 \pm 0.23^{\mathrm{c}}$ & $4.63 \pm 0.74^{\mathrm{b}}$ & $13.41 \pm 0.36^{\mathrm{ab}}$ & $1.44 \pm 0.14^{\mathrm{c}}$ & $1.66 \pm 0.19^{\mathrm{d}}$ \\
\hline & $3.6-\mathrm{R}$ & $31.59 \pm 1.61^{\mathrm{b}}$ & $42.82 \pm 2.77^{\mathrm{b}}$ & $2.20 \pm 0.12^{\mathrm{c}}$ & $2.29 \pm 0.23^{\mathrm{cd}}$ & $13.77 \pm 1.62^{\mathrm{ab}}$ & $1.42 \pm 0.12^{\mathrm{c}}$ & $1.79 \pm 0.15^{\mathrm{cd}}$ \\
\hline
\end{tabular}

${ }^{\mathrm{a}-\mathrm{f}}$ Values within a column without common superscripts per dissociating agent are significantly different $(P<0.05)$.

${ }^{1}$ Mean value \pm standard error; $\mathrm{n}=6$ for raw milk $(\mathrm{R})$ and $\mathrm{n}=3$ for milk subjected to conventional homogenization-pasteurization $(\mathrm{H})$ and milk subjected to ultra-high-pressure homogenization (U).

${ }^{2}$ Values $0.0,1.8$, and 3.6 are milk fat contents $(\%)$.

results (Lefebvre-Cases et al., 1998; Gagnaire et al., 2002), a much higher level of release of protein occurred in the presence of urea (Table 2) than with water or EDTA. The proteins involved were mainly caseins (Figures 1 and 2; Table 4). However, the levels of dissociation varied depending on the fat content of milk. Increasing milk fat content decreased the amount of protein dissociated by urea, suggesting that caseins are partly linked through hydrogen bonds within the curd, which the presence of fat could inhibit. In particular, the proportion of para- $\kappa-\mathrm{CN}$ in the supernatants decreased with increasing fat content. In model systems, native milk fat globules are considered as noninteracting particles and act as inert fillers (Métais et al., 2006). However, the inclusion of native fat globules in a drained curd would keep casein micelles apart, thus reducing the amount of para- $\kappa-\mathrm{CN}$ linked through hydrogen bonds. Regardless of milk fat content, conventional homogenizationpasteurization increased the dissociation of proteins by urea (Table 2); small fat globules may not perturb the formation of the protein network (Lopez and Dufour, 2001). However, UHPH either had little effect on the extent of dissociation with urea for curds prepared from $1.8 \%$-fat milk, or reduced dissociation for $3.6 \%$-fat milk. The incorporation of whey proteins (i.e., $\beta-\mathrm{LG}$ and $\alpha$-LA) into the curd by means of other bonds (e.g., hydrophobic interactions) may lead to greater difficulty in creating hydrogen bonds due to spatial competition.

Sodium dodecyl sulfate breaks hydrophobic interactions by inducing intramolecular electrostatic repulsion. In accordance with previous results (Lefebvre-Cases et al., 1998), the use of SDS resulted in almost complete dissociation of the curd (Table 2), with no significant effect of fat level. However, both homogenization treatments significantly affected the dissociation of protein, and the protein pattern differed, depending on both the treatment and the absence or presence of fat (Figures 1 and 2). For curd made from $0.0 \%$-fat milk, conventional homogenization-pasteurization significantly increased the level of caseins dissociated by SDS (i.e., $\alpha_{\mathrm{s}}-\mathrm{CN}$, $\beta-\mathrm{CN}$, and $\kappa-\mathrm{CN}$; Table 4$)$; for UHPH-treated skim milk, the proteins dissociated were mainly $\kappa-\mathrm{CN}$ and $\gamma_{2}-/ \gamma_{3}$-CN. In contrast, UHPH increased the level of dissociation by SDS of both whey proteins ( $\beta$-LG and $\alpha-\mathrm{LA})$, and caseins $\left(\alpha_{\mathrm{s}}-\mathrm{CN}\right.$ and $\left.\beta-\mathrm{CN}\right)$. Although, in early studies on UHPH, no denaturation of whey proteins was reported (Hayes and Kelly, 2003; Sandra and Dalgleish, 2005), these results support those obtained in more recent studies (Zamora et al., 2007; Pereda et al., 2009) that UHPH and, to a lesser extent, conventional homogenization-pasteurization caused the incorporation of denatured whey proteins into the curd.

\section{CONCLUSIONS}

Increasing the fat content of raw milk impaired hydrogen bonding between caseins within drained curds. Both conventional and UHPH increased the amount of unbound whey proteins and calcium-bonded caseins in curds. Significant differences were observed in the extent of hydrogen bonding and hydrophobic interactions in curds between the 2 treatments. Conventional homogenization-pasteurization enhanced casein-casein interactions, through hydrogen bonds and hydrophobic 
interactions and, when fat was present, the incorporation of $\alpha-\mathrm{LA}$ in the curd through hydrophobic interactions. In contrast, UHPH impaired hydrogen bonding and favored hydrophobic interactions of whey proteins and caseins.

\section{ACKNOWLEDGMENTS}

The authors acknowledge the technological support from J. McNamara and T. Uniacke (School of Food and Nutritional Sciences, University College Cork, Cork, Ireland). A. Zamora acknowledges the predoctoral fellowship from the Ministerio de Educación y Ciencia (Spanish government).

\section{REFERENCES}

Alessi, A., A. Fontana, P. Risso, C. Gatti, and M. Pires. 2007. Identification of interactions involved in rennet gel structures using dissociating chemical agents. Colloid Polym. Sci. 285:1281-1286.

Daviau, C., M.-H. Famelart, A. Pierre, H. Goudédranche, and J.-L. Maubois. 2000. Rennet coagulation of skim milk and curd drainage: Effect of $\mathrm{pH}$, casein concentration, ionic strength and heat treatment. Lait 80:397-415.

Gagnaire, V., E. Trotel, Y. Le Graët, and J. Léonil. 2002. Role of electrostatic interactions in the curd of Emmental cheese. Int. Dairy J. 12:601-608.

Ghosh, B. C., A. Steffl, J. Hinrichs, and H. G. Kessler. 1994. Rennetability of whole milk homogenized before and after pasteurization. Milchwissenschaft 49:363-367.

Green, M. L., R. J. Marshall, and F. A. Glover. 1983. Influence of homogenization of concentrated milks on the structure and properties of rennet curds. J. Dairy Res. 50:341-348.

Hayes, M. G., and A. L. Kelly. 2003. High pressure homogenisation of raw whole bovine milk (a) effects on fat globule size and other properties. J. Dairy Res. 70:297-305.

Hinrichs, J., and S. Keim. 2007. Process-induced stabilizing bonds in fermented milk products. Milchwissenschaft 62:422-425.

Humbert, G., A. Driou, J. Guerin, and C. Alais. 1980. Effets de l'homogénéisation à haute pression sur les propriétés du lait et son aptitude à la coagulation enzymatique. Lait 599-600:574-594.

IDF (International Dairy Federation). 1993. Milk-Determination of the nitrogen (Kjeldahl method) and calculation of the crude protein content. IDF Standard 20B. IDF, Brussels, Belgium.

IDF (International Dairy Federation). 2000. Whole milk-Determination of milkfat, protein and lactose content - Guide for the operation of mid-infrared instruments. IDF Standard 141C. IDF, Brussels, Belgium.

IDF (International Dairy Federation). 2004. Cheese and processed cheese-Determination of the total solids content (Reference Method). IDF Standard 004:2004. IDF, Brussels, Belgium.

ISO (International Organization for Standardization). 1975. CheeseDetermination of fat content - van Gulik method. ISO Standard 3433. ISO, Leusden, the Netherlands.

Jana, A. H., and K. G. Upadhyay. 1992. Homogenisation of milk for cheesemaking - A review. Aust. J. Dairy Technol. 47:72-79.

Laemmli, U. K. 1970. Cleavage of structural proteins during the assembly of the head of bacteriophage T4. Nature 227:680-685.

Lanciotti, R., L. Vannini, F. Patrignani, L. Iucci, M. Vallicelli, M. Ndagijimana, and M. E. Guerzoni. 2006. Effect of high pressure homogenisation of milk on cheese yield and microbiology, lipolysis and proteolysis during ripening of Caciotta cheese. J. Dairy Res. $73: 216-226$.
Lefebvre-Cases, E., E. Gastaldi, V. Vidal, S. Marchesseau, A. Lagaude, J.-L. Cuq, and B. Tarodo De La Fuente. 1998. Identification of interactions among casein gels using dissociating chemical agents. J. Dairy Sci. 81:932-938.

Lodaite, K., F. Chevalier, E. Armaforte, and A. L. Kelly. 2009. Effect of high-pressure homogenisation on rheological properties of rennet-induced skim milk and standardised milk gels. J. Dairy Res. 76:294-300.

Lopez, C., and E. Dufour. 2001. The composition of the milk fat globule surface alters the structural characteristics of the coagulum. J. Colloid Interface Sci. 233:241-249.

Lowry, O. H., N. J. Rosebrough, A. L. Farr, and R. J. Randall. 1951. Protein measurement with the Folin phenol reagent. J. Biol. Chem. 193:265-275.

McMahon, D. J., and R. J. Brown. 1984. Enzymic coagulation of casein micelles: A review. J. Dairy Sci. 67:919-929.

Métais, A., M. Cambert, A. Riaublanc, and F. Mariette. 2006. Influence of fat globule membrane composition on water holding capacity and water mobility in casein rennet gel: A nuclear magnetic resonance self-diffusion and relaxation study. Int. Dairy J. $16: 344-353$.

Metzger, L. E., and V. V. Mistry. 1994. A new approach using homogenization of cream in the manufacture of reduced fat Cheddar cheese. 1. Manufacture, composition, and yield. J. Dairy Sci. 77:3506-3515.

Michalski, M. C., R. Cariou, F. Michel, and C. Garnier. 2002. Native vs. damaged milk fat globules: membrane properties affect the viscoelasticity of milk gels. J. Dairy Sci. 85:2451-2461.

Pereda, J., V. Ferragut, J. M. Quevedo, B. Guamis, and A. J. Trujillo. 2007. Effects of ultra-high pressure homogenization on microbial and physicochemical shelf life of milk. J. Dairy Sci. 90:1081-1093.

Pereda, J., V. Ferragut, J. M. Quevedo, B. Guamis, and A. J. Trujillo. 2009. Heat damage evaluation in ultra-high pressure homogenized milk. Food Hydrocoll. 23:1974-1979.

Peters, I. I. 1956. Cheddar cheese made from pasteurized milk homogenized at various pressures. J. Dairy Sci. 39:1083-1088.

Roach, A., and F. Harte. 2008. Disruption and sedimentation of casein micelles and casein micelle isolates under high-pressure homogenization. Innov. Food Sci. Emerg. Technol. 9:1-8.

Sandra, S., and D. G. Dalgleish. 2005. Effects of ultra-high-pressure homogenization and heating on structural properties of casein micelles in reconstituted skim milk powder. Int. Dairy J. 15:10951104.

Sandra, S., and D. G. Dalgleish. 2007. The effect of ultra high-pressure homogenization $(\mathrm{UHPH})$ on rennet coagulation properties of unheated and heated fresh skimmed milk. Int. Dairy J. 17:10431052.

Walstra, P., H. J. M. van Dijk, and T. J. Geurts. 1985. The syneresis of curd. 1. General considerations and literature review. Neth. Milk Dairy J. 39:209-246.

Zamora, A., V. Ferragut, B. Guamis, and A. J. Trujillo. 2012a. Changes in the surface protein of the fat globules during ultra-high pressure homogenisation and conventional treatments of milk. Food Hydrocoll. http://dx.doi.org/10.1016/j.foodhyd.2012.02.012.

Zamora, A., V. Ferragut, P. D. Jaramillo, B. Guamis, and A. J. Trujillo. 2007. Effects of ultra-high pressure homogenization on the cheese-making properties of milk. J. Dairy Sci. 90:13-23.

Zamora, A., V. Ferragut, B. Juan, B. Guamis, and A. J. Trujillo. 2011. Effect of ultra-high pressure homogenisation of milk on the texture and water-typology of a starter-free fresh cheese. Innov. Food Sci. Emerg. Technol. 12:484-490.

Zamora, A., V. Ferragut, J. M. Quevedo, B. Guamis, and A. J. Trujillo. 2012b. Ultra-high pressure homogenisation of milk: Technological aspects of cheese-making and microbial shelf life of a starter-free fresh cheese. J. Dairy Res. http://dx.doi.org/10.1017/ S0022029912000052. 